\title{
Stage-specific selection of alternative transcriptional initiation sites from the 5C actin gene of Drosophila melanogaster
}

\author{
Jim O. Vigoreaux ${ }^{1}$ and Sara L. Tobin ${ }^{2}$ \\ Department of Biochemistry and Molecular Biology, University of Oklahoma Health Sciences Center, Oklahoma City, \\ Oklahoma 73190 USA
}

\begin{abstract}
The transcription unit of the $5 \mathrm{C}$ actin gene exhibits a complex organization that is unique among the six actin genes of Drosophila melanogaster. Three different mRNA size classes showing distinct patterns of accumulation throughout development are detected on Northern blots. We have determined the structure of the various $5 \mathrm{C}$ actin transcripts by exon mapping using strand-specific RNA probes, primer extension analysis, and DNA sequences analysis of both cDNA and genomic clones. All the transcripts share a single protein-coding nucleotide sequence but are heterogeneous in the $5^{\prime}$ and $3^{\prime}$ untranslated regions. The $5^{\prime}$ untranslated region of each transcript consists of either one of two small exons (exon 1 and exon 2) which are alternatively spliced to a single acceptor site 8 bp upstream from the translation initiation codon in exon 3. Results from primer extension analysis suggest that transcription can initiate from either exon 1 or exon 2, and also from a third site within exon 2. We detect an increase in the relative abundance of exon 1-containing transcripts at larval and pupal stages, as well as a change in the proportion of transcripts that initiate at either of the two exon 2 sites. Five polyadenylation sites have been found within three termination/processing regions that define the three size classes of polyadenylated transcripts. The results of our experiments indicate the existence in vivo of all possible combinations of $5^{\prime}$ exon with $3^{\prime}$ polyadenylation site. However, particular combinations of $5^{\prime}$ initiation site and $3^{\prime}$ polyadenylation site are preferred at certain developmental stages.
\end{abstract}

[Key Words: 5C actin gene; alternate promoters; developmental regulation; Drosophila; 3' end heterogeneity]

Received May 28, 1987; revised version accepted October 14, 1987.

During recent years a number of genes have been shown to consist of complex transcriptional units that produce a variety of combinations of differing primary transcripts coupled to differential post-transcriptional processing events (for review, see Leff et al. 1986). Analysis of these transcriptional units has defined new levels of gene regulation and has modified our concept of the genetic unit. Diverse strategies have been revealed by which differential expression of a single gene can be accomplished. Some examples include alternative use of transcription initiation sites (Carlson and Botstein 1982; Benyajati et al. 1983; Schibler et al. 1983) or 3' polyadenylation sites (Capetanaki et al. 1983), differential splicing of primary transcripts (Breitbart et al. 1985; Cooper and Ordahl 1985 ), or any combination of these mechanisms (Early et al. 1980; Rosenfeld et al. 1983; Nabeshima et al. 1984; Periasamy et al. 1984; Robert et al. 1984). In these cases, the particular choice of promoter, polyadenylation site, or splicing pathway is utilized in a tissue-specific and/or development-specific mode. This diversity can result in

'Present address: Department of Biology 16-719, Massachusetts Institute of Technology, Cambridge, Massachusetts 02139 USA.

${ }^{2}$ Corresponding author: Dr. Sara L. Tobin, Department of Biochemistry and Molecular Biology, O.U.H.S.C., P.O. Box 26901, Oklahoma City, Oklahoma 73190 USA. different transcripts coding for variants of the same protein that have become specialized for the particular cell type or developmental period during which they are expressed (Caplan et al. 1983). On the other hand, several examples have been described in which multiple transcripts from a single gene encode identical proteins but differ in the length and sequence of their $5^{\prime}$ and/or $3^{\prime}$ untranslated regions (Bennetzen and Hall 1982; Freytag et al. 1984; McGrogan et al. 1985; Schneuwly et al. 1986; Urano et al. 1986). The function of these transcribed but untranslated sequences is not known, but it has been speculated that they might be involved in translational efficiency (Darveau et al. 1985), mRNA (in)stability (Belasco et al. 1986), or cellular targeting of transcripts (Lawrence and Singer 1986). The study of genes that produce multiple transcripts differing in noncoding sequences may elucidate whether these untranslated regions have a function in post-transcriptional regulation of gene expression.

A common feature of most eukaryotic genomes is an actin multigene family (Firtel 1981; Buckingham and Minty 1983). Since actin is a ubiquitous protein involved in a variety of cellular, morphological, and developmental events, multigene families can offer several advantages to the organism. Repeated copies of a gene 
can produce a greater amount of product than could a single-copy gene, a phenomenon refered to as dosage repetition (Finnegan et al. 1977; Long and Dawid 1980). Either alternatively or in addition to dosage repetition, each member of a multigene family could code for an isoform with a specialized function (Whalen et al. 1981; Weydert et al. 1983; Caplan et al. 1983) and/or possess an independent regulatory program that allows each gene to respond to a different developmental or tissuespecific cue (McKeown and Firtel 1981; Davidson et al. 1982; Garcia et al. 1984; Mohun et al. 1984; Cox et al. 1986). In Drosophila melanogaster, six actin genes have been shown to encode proteins whose amino acid sequences share greater than $85 \%$ homology (Tobin et al. 1980; Fyrberg et al. 1981; Sanchez et al. 1983). While the protein products are similar, each actin gene exhibits a unique profile of transcript accumulation throughout development (Fyrberg et al. 1983; Sanchez et al. 1983), suggesting that they have evolved independent regulatory programs.

The actin gene found at polytene chromosome locus $5 \mathrm{C}$ has been identified as a cytoplasmic actin gene (Fyrberg et al. 1980). In addition, Couderc et al (1983) have shown that expression of the $5 \mathrm{C}$ actin gene is modulated by the molting hormone ecdysterone. The $5 \mathrm{C}$ actin gene differs from the other five Drosophila actin genes in one more respect: It is the only actin gene that is transcribed into developmentally regulated transcripts of different size classes (Fyrberg et al. 1983; Vigoreaux 1987). To understand the mechanism/s $\mid$ responsible for differential expression of the $5 \mathrm{C}$ actin gene, we have determined the molecular organization of this gene and examined the structure of its multiple mRNA species. In this paper, we demonstrate that multiple mature $5 \mathrm{C}$ actin transcripts share a common protein coding region but differ in their utilization of $5^{\prime}$ exons and $3^{\prime}$ polyadenylation sites during development. Bond and Davidson (1986) have presented evidence regarding the structure of the various $5 \mathrm{C}$ actin transcripts. Our results confirm some of their conclusions and in addition, we present the first report of developmentally regulated alternative $5^{\prime}$ initiation sites and splicing patterns in an actin gene in any organism.

\section{Results \\ Isolation and characterization of $5 \mathrm{C}$ actin genomic DNA and transcripts}

Figure 1A shows a partial restriction endonuclease map of RI-19, an 8.4-kb EcoRI genomic fragment containing the entire 5C actin gene isolated from a recombinant $\lambda$ phage Drosophila genomic library (Maniatis et al. 1978). The entire amino acid coding region is located within a 1.9-kb HindIII-HindIII fragment, as determined by DNA sequence analysis (Fig. 1B). The protein-coding nucleotide sequences are highly conserved among Drosophila actin genes (Fyrberg et al. 1981; Sanchez et al. 1983). To study the accumulation of 5C actin homologous RNA, we used gene-specific probes that represent single-copy genomic sequences, do not contain protein coding nucleotides, and do not cross-react with heterologous transcripts. The 5' 3.7-kb EcoRI-HindIII fragment and the 3' 1.6-kb HindIII-HindIII fragment (Fig. 1A) fulfill these criteria (data not shown). Our preliminary studies on the patterns of accumulation of $5 \mathrm{C}$ actin transcripts were carried out with these probes.

These studies confirmed the finding that the $5 \mathrm{C}$ actin gene produces multiple transcripts (Fyrberg et al. 1983) and permitted us to focus our experiments on the developmental stages at which the greatest variation in accumulation of the different transcript size classes was observed. The $5 \mathrm{C}$ actin gene had been suggested by R-loop studies to consist of two exons: a short (70-170 bp) 5' "leader" exon and a 1.55-kb exon containing the major portion of the gene (Fyrberg et al. 1980). However, this structure cannot, by itself, account for the generation of the various transcripts from this gene. We have carried out a detailed analysis of the structure of the $5 \mathrm{C}$ actin gene to determine which regions of the gene are represented in the several transcript size classes.

\section{Characterization of different cDNAs and DNA sequence of corresponding genomic regions}

We characterized several different actin cDNA clones that were identified as 5C-derived on the basis of their homology to either the $5^{\prime}$ or $3^{\prime}$ gene-specific probes (Fig.

Figure 1. Structure and partial restriction map of the 5C actin genomic clone and cDNA clones. (A) RI-19 is an 8.4-kb Drosophila genomic fragment containing the entire $5 \mathrm{C}$ actin gene. Boxed areas represent exons; filled boxes represent the protein-coding domain, and striped boxes represent the noncoding regions. Horizontal arrows indicate the extent and direction of sequencing from the indicated restriction site. Arrows with filled circles indicate fragments generated by Bal31. The strategy shown was that used to generate the sequence shown in Fig. 1B. Only restriction sites used to generate probes or sequencing fragments are shown. The two subfragments used as gene-specific probes are indicated above the map. $(B)$ DNA sequences of the $5^{\prime}$ - and $3^{\prime}$ - flanking regions of the $5 \mathrm{C}$ actin genomic and cDNA clones. +1 refers to the first amino acid-coding nucleotide. Nucleotides upstream from the open reading frame are given negative numbers, beginning with -1 for the first nucleotide preceding the ATG translation initiation codon. The region from -1062 to -1026 was not sequenced; numbering upstream from this 37-nucleotide gap was calculated following the sequence of Bond and Davidson (1986). Exons are in boldface italics with arrows indicating the $5^{\prime}$ and $3^{\prime}$ boundaries of the different cDNA clones. Locations of transcriptional start sites as determined by primer extension analysis are indicated by plus signs. The coding region sequence, which is common among all 5C actin transcripts, is not shown in its entirety. Putative regulatory elements (TATA box and polyadenylation signals) are indicated by brackets. Asterisks indicate mismatches between this sequence and the following previously published sequences: Parker and Topol (1984) from - 1883 to - 1781; Bond and Davidson (1986) from -2024 to -1608 , -1148 to -371 , and -52 to +36 ; Fyrberg et al. (1981) from -8 to +225 . Relevant restriction endonuclease cleavage sites are shown, with the points of cleavage indicated by an open triangle. 
A

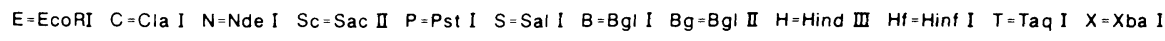

B

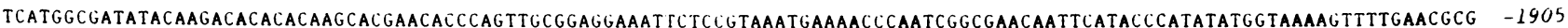

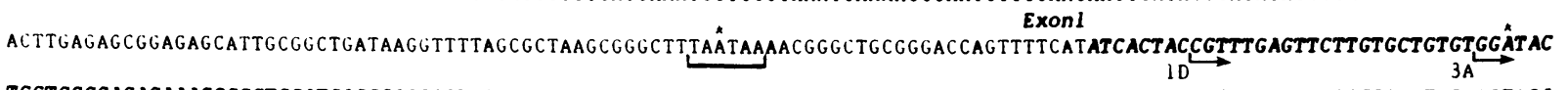

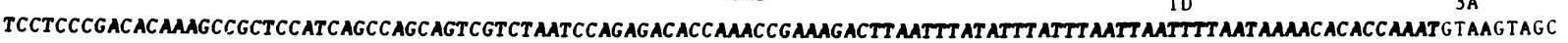

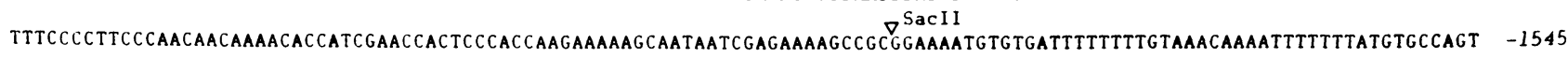

GCTGAAAGTGATCAAAAAATACTAGCCACGAGCTAAAGAGTTATTGTATTGACCAAAACTCCAAAAATACCCAAGTTTGGCCCTAAATTGTCAATCAAAATACCAATAGGTCGAAGGACA -1425

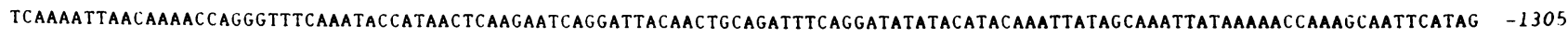

CCCCAACTCAAATGTTAGGATCTAATATAGTGTTTAAAGCCAAGCTCGCTGATGTGGGCGTGTCACGATTTCACCCAAAGaTATGCCAAATTACGAaTTGCAAATCAATTCGCCAACACT -1185

TCTTTTTTICCCACGCCTAAAACACAGATCATCATAAATGTACATACATACAGTATATGCATATTATAATCTGTAÅACTAGATCAGGTTCTTGAAAATAGTGACGTAGG̊aGCCGTTTTGG -1065

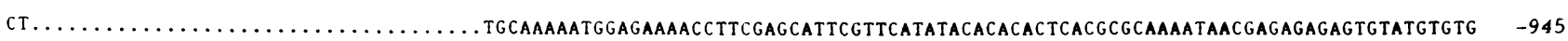

TGTGAGAGAGCGAAAGCCAGACGACGgTTTGCTTTTCGCCTCGAAACATGACCATATATGgTCACAAAACTTGGCGCCGCAATTCAACACACCAGCGCTCTCCTTCGCACCCATAGCGA -825

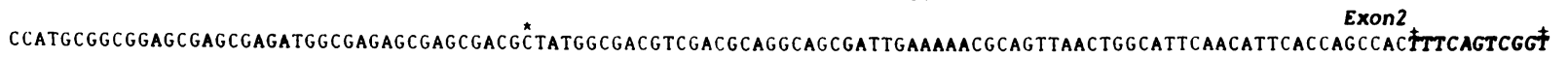

TTATTCCAGTCATTCCTTTCAAACCGTGCGGTCGCTTAGCTCAGCCTCGCCACTTGCGTTTACAGT AGTTTTCACGCCTTGAATTGTTAAACGAACAAAAGG TAAAGTTTAACTAGC

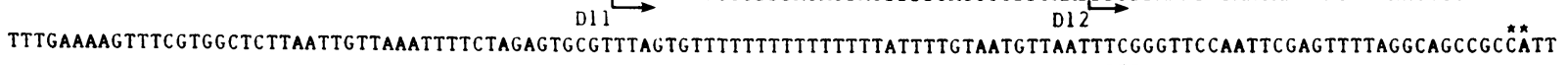

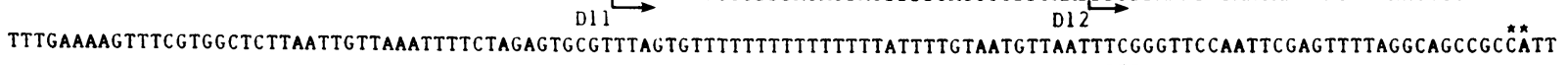

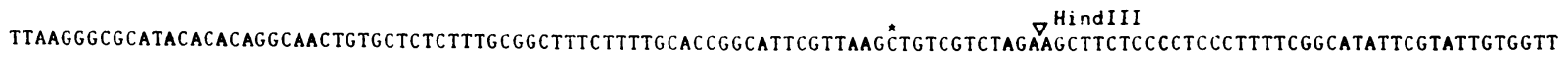

TTAATTTTTCGGGGCGGGGCTTCTATTTTGTAACTGTTCTTTTAATTTCTTATTACAATTCGATCGCAAGTGAAAATCAGTTTTCAATCGGAAAAGTATTTTTTTATGAAATTTTTTITT

GTCCAAGATTAAAATTTTGTACTAAAAAAACGTACATTGCATTGAGTGATTTTTAATTGTACACGAAAACAAGTTAGTTTGTTATGACAATTGTACTTTGGTAGACCAGCGCAGTCCAA Exon3 $+1$

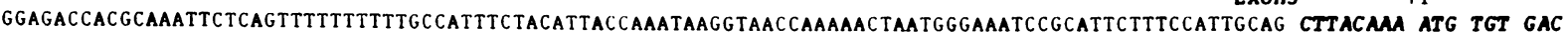

MET Cys Asp

GA GA GTT GCT GCT CTG GTT GTC GAC MAC GGC TCT GGC ATG TGC MAG GCC GGA TTT GCC GGA GAC GAT GCT CCC CGC GCC GTC TTC CCA Glu Glu Val Ala Ala Leu Val Val Asp Asn Gly Ser Gly Met Cys Lys Ala Gly Phe Ala Gly Asp Asp Ala Pro Arg Ala Val Phe Pro

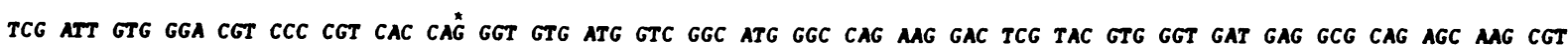
Ser Ile Val Gly Arg Pro Arg His Gin Gly Val Met Val Gly Met Gly Gin Lys Asp Ser Tyr Val Gly Asp Glu Ala Gln Ser Lys Arg

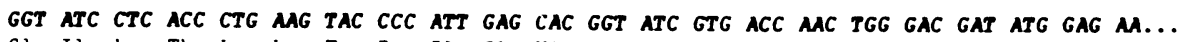

Gly Ile Leu Thr Leu Lys Tyr Pro Ile Glu His Gly Ile Val Thr Asn Trp Asp Asp Met Glu SalI

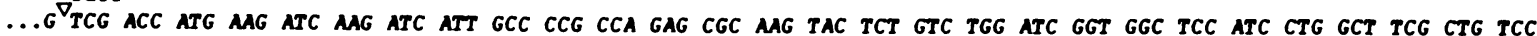
Ser Thr Met lys Ile Lys Ile Ile Ala Pro Pro Gly Arg Lys Tyr Ser Val Trp Ile Gly Gly Ser Ile Leu Ala Ser Leu Ser

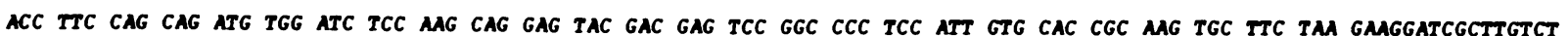
Thr Phe Gln Gln Met Trp Ile Ser Lys Gln Glu Tyr Asp Glu Ser Gly Pro Ser Ile Val His Arg Lys Cys Phe "

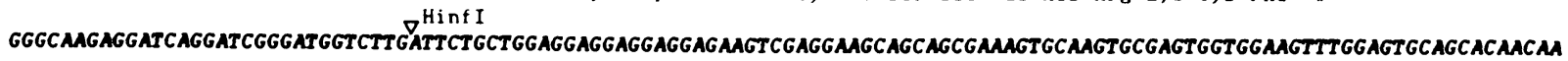

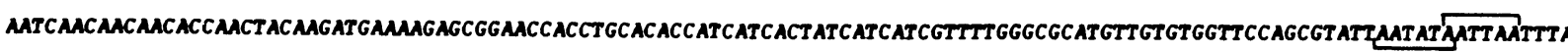

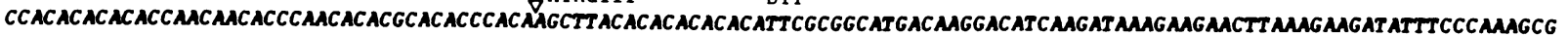

Figure 1. (See facing page for legend.) 
1A). $\mathrm{pD} 11$ and $\mathrm{pD} 12$ were isolated from an ecdysteroneinduced third instar salivary gland cDNA library (Wolfner 1980), while p3A and p1D were isolated from an imaginal disc cDNA library (kindly provided by $\mathrm{J}$. Fristrom). The DNA sequence of the $5^{\prime}$ and 3 ' noncoding regions, as well as parts of the coding region, was determined for all these clones. A comparison with the sequence of the corresponding genomic regions is shown in Figure 1B. All cDNAs exhibit a common 5' splice site located eight nucleotides upstream from the translation initiation codon ATG. However, the sequences preceding the splice site differ. cDNAs p3A and plD contain sequences that are homologous to a genomic region located $1.66 \mathrm{~kb}$ upstream from the splice site. On the other hand, the $5^{\prime}$ ends of $\mathrm{pD} 11$ and $\mathrm{pD} 12$ are homologous to a genomic region separated from the splice site by a $0.59-\mathrm{kb}$ intron.

The cDNAs differ in the lengths of their 3' noncoding regions (see Fig. 1B). The DNA sequence of all four cDNAs is colinear with the genomic sequence, indicating that there are no splices in the $3^{\prime}$ region of the gene. The difference in length arises from differential termination and/or cleavage/polyadenylation sites. Ribonuclease-protected fragments corresponding to the length of the $3^{\prime}$ ends of these cDNA clones confirm that these cDNAs represent genuine $3^{\prime}$ ends (see below).

\section{$5^{\prime}$ end analysis of the 5C actin transcripts}

The $5^{\prime}$ ends of the mature $5 \mathrm{C}$ actin transcripts were defined by quantitative RNase protection mapping, primer extension analysis, and DNA sequence analysis of cDNA clones and the corresponding regions of the genomic clone. Figure 2 shows results of ribonuclease protection experiments in which in vitro-generated singlestranded RNA probes corresponding to the $5^{\prime}$ region of the gene were hybridized to poly(A) RNA from different developmental stages. Three small fragments of approximately 150 nucleotides, 114 nucleotides, and 104 nucleotides are protected by probe 1 . Identical results were obtained with a probe corresponding to the entire 5 ' 3.7$\mathrm{kb}$ EcoRI-HindIII region (results not shown). Probe 2, on the other hand, only protects the 114- and 104-nucleotide fragments. These results suggest that the 150-nucleotide fragment corresponds to an exon located between the NdeI and BglI sites (exon 1 in Fig. la). The 114- and 104-nucleotide protected fragments could correspond to two separate exons whose boundaries lie within the BgII and HindIII sites or, alternatively, one exon with two different $5^{\prime}$ or $3^{\prime}$ termini. This question was resolved by primer extension analysis using a 69nucleotide, 5'-end-labeled SalI-TaqI fragment corresponding to nucleotides +32 to +100 . As template, we used hybrid-selected mRNA homologous to a $5 \mathrm{C}$ actin gene specific probe to eliminate cross-hybridization with other actin gene transcripts. Three extension products of 142,152, and 190 nucleotides were obtained (Fig. 3A). These results suggest that there is a one-to-one correlation between extension products and the fragments protected by RNase digestion, since the difference in length among the three extension products is similar to that among the three protected fragments. This conclusion is further supported by the available sequence from the cDNAs (Fig. 1B).

These results, together with those from ribonuclease protection experiments, indicate that exon 1 is approximately $150 \mathrm{bp}$ in length. A variant of the Drosophila cap consensus sequence ATCA $/ \mathrm{G} / \mathrm{T}) \mathrm{T} / \mathrm{T} / \mathrm{C}$ ) (Hultmark et al. 1986 ) is found 8 nucleotides upstream from the $5^{\prime}$ end of pID (ATCACTA, from -1820 to -1814 , Fig. 1B). If transcription initiates at this site, then exon 1 would be 147 nucleotides, which agrees very closely with the size determined by both protection assays and primer extensions. Consequently, we assigned the $\mathrm{A}$ at position -1820 as the transcription initiation site for exon 1 .

A second extension analysis was performed using a 53-bp primer isolated from cDNA clone $\mathrm{pD} 11$. The 5' end of this clone extends only 57 nucleotides from the splice site to exon 3 (Fig. 1B). Its genomic counterpart corresponds to nucleotides -657 to -601 , which are located within the region where the 114- and 104-nucleotide ribonuclease-protected fragments map. To determine the relationship between the protected fragments and the $5^{\prime}$ end of $\mathrm{pD} 11$, primer extension analysis was carried out with RNAs from various developmental stages (Fig. 3B). With the exception of 90-99 hr RNA, extension products of approximately 54 and 63 nucleotides were obtained with RNA from all the other stages. These results suggest that the 114- and 104-nucleotide protected fragments correspond to a single exon with two alternative initiation sites. In addition, we were unable to detect an extension product that would correspond to the usage of exon 1 and exon 2 in the same RNA molecule, confirming our conclusion that exon 1 and exon 2 are alternatively spliced to exon 3 .

Hybridization of $5^{\prime}$ probes to Nothern blots of poly(A) RNA indicate that both exon 1 and exon 2 are utilized in all three size classes of transcripts (Fig. 2B-D). To estimate the relative abundance of exon 1-containing transcripts versus exon 2-containing transcripts, we quantitated the intensity of the signals generated in three comparable ribonuclease protection experiments (Fig. 2E) using a scanning densitometer. As seen in Table 1, exon 1 -containing transcripts are more abundant than exon 2containing transcripts in all three stages examined. However, there is a twofold increase in the proportion of transcripts containing exon 1 in 90-99 hr larval RNA and $150-158 \mathrm{hr}$ pupal RNA as compared to $0-12 \mathrm{hr}$ embryo RNA. A second observation is that transcripts containing exon $2 \mathrm{~A}$ are twice as abundant as transcripts containing exon $2 \mathrm{~B}$ at $90-99 \mathrm{hr}$ and $150-158 \mathrm{hr}$, while their ratio is almost $1: 1$ at $0-12 \mathrm{hr}$. This modulation of $5 \mathrm{C}$ actin transcripts could result from a preferential stability of particular transcripts as a function of development or from state-specific control mechanisms involved in the selection of $5^{\prime}$ initiation site.

\section{Coding region and $3^{\prime}$ end analysis of the $5 \mathrm{C}$ actin transcripts}

Ribonuclease protection experiments were also carried 


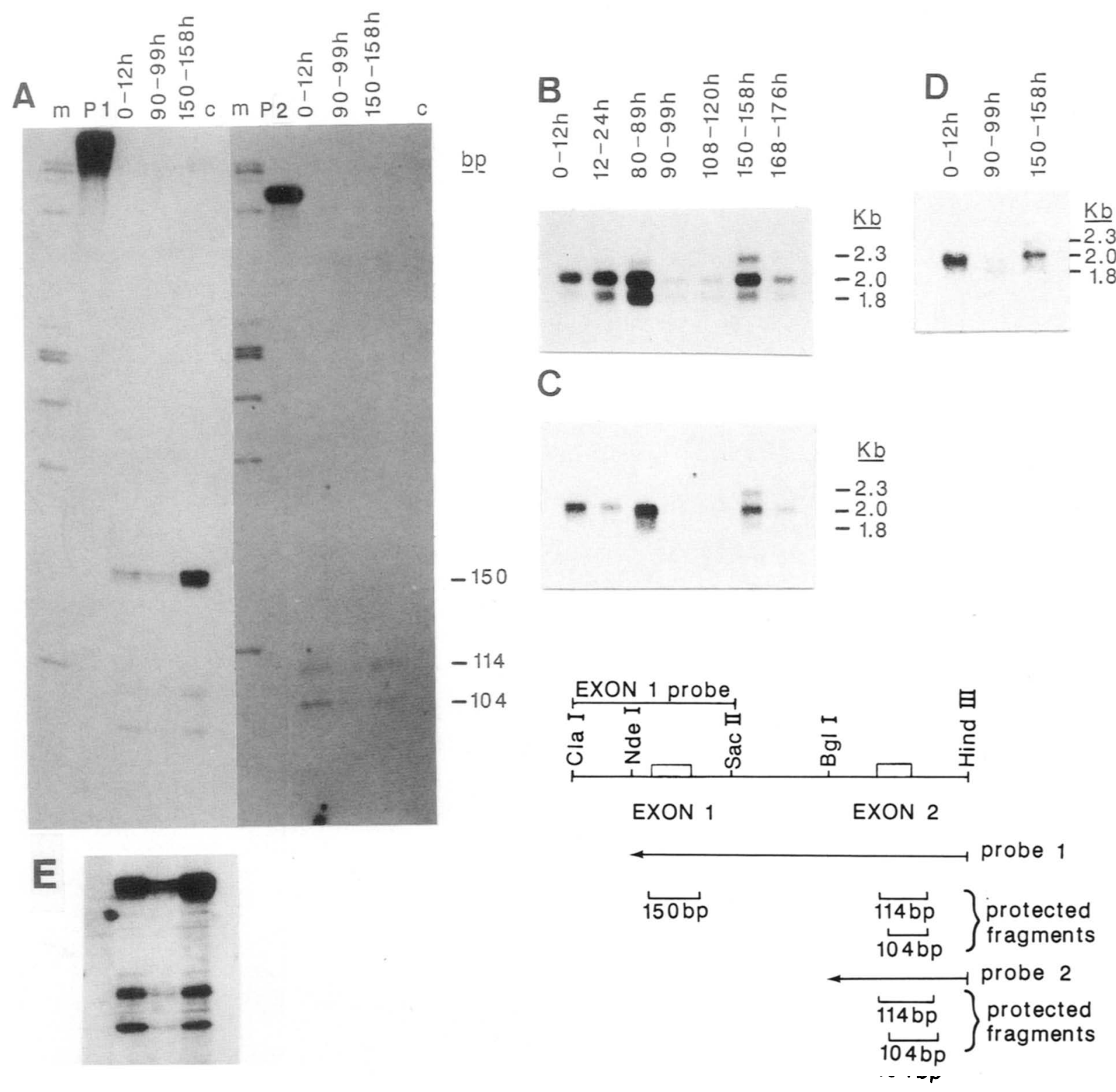

Figure 2. (A) RNase protection analysis of $5 \mathrm{C}$ actin transcripts. Mapping the $5^{\prime}$ end of the gene. The $5^{\prime} 3.7-\mathrm{kb}$ EcoRI-HindIII genomic fragment was cloned into the SP6 polymerase vector pSP64 and used to generate overlapping probes by linearizing at the NdeI site (probe 1) and BglI site (probe 2). (m) $\phi \mathrm{X}$ 174-HaeIII digest used as molecular weight standards; (P) undigested probe; 0-12 hr embryo poly(A) RNA, 90-99 hr larvae poly(A) RNA, 150-158 hr pupae poly(A) RNA, and yeast tRNA (c) used as control. Numbers on the right margin refer to the size of the protected fragments. $(B-D)$ Northern blots hybridized to probe 1 , probe 2 , and a 0.8 -kb ClaI-SacII probe (exon 1 probe in diagram), respectively. All blots were exposed for $20 \mathrm{hr}(E)$ Overexposure of autoradiogram $A$ (144-hr exposure).

out with probes corresponding to the entire coding region of the $5 \mathrm{C}$ actin gene and extending $2.0 \mathrm{~kb}$ downstream from the translational stop (data not shown). The conclusions drawn from these data suggest that exon 3 , which contains the entire protein coding region, is contiguous with the $3^{\prime}$ end of the gene. The differential lengths of the transcripts are generated by $3^{\prime}$ cleavage/ polyadenylation sites that attenuate the primary transcript at different points. Three major cleavage/polyadenylation regions with three major and two minor polyadenylation sites were identified. Each of the cDNA clones analyzed above corresponded to a site identified by these ribonuclease protection assays. The results of these experiments closely parallel those of Bond and Davidson (1986), with the addition of our detection of the two minor cleavage/polyadenylation sites summarized in Figure 4. These results indicate that the $3^{\prime}$ ends of the $1.8-\mathrm{kb}$ transcripts as well as the $3^{\prime}$ ends of the $2.0-\mathrm{kb}$ transcripts are heterogeneous.

\section{Discussion}

The major results of this study are summarized in Figure 4. We have determined the structure of the $5 \mathrm{C}$ actin gene and have shown that it consists of one large exon (exon 3) containing the protein-coding and 3 ' noncoding 

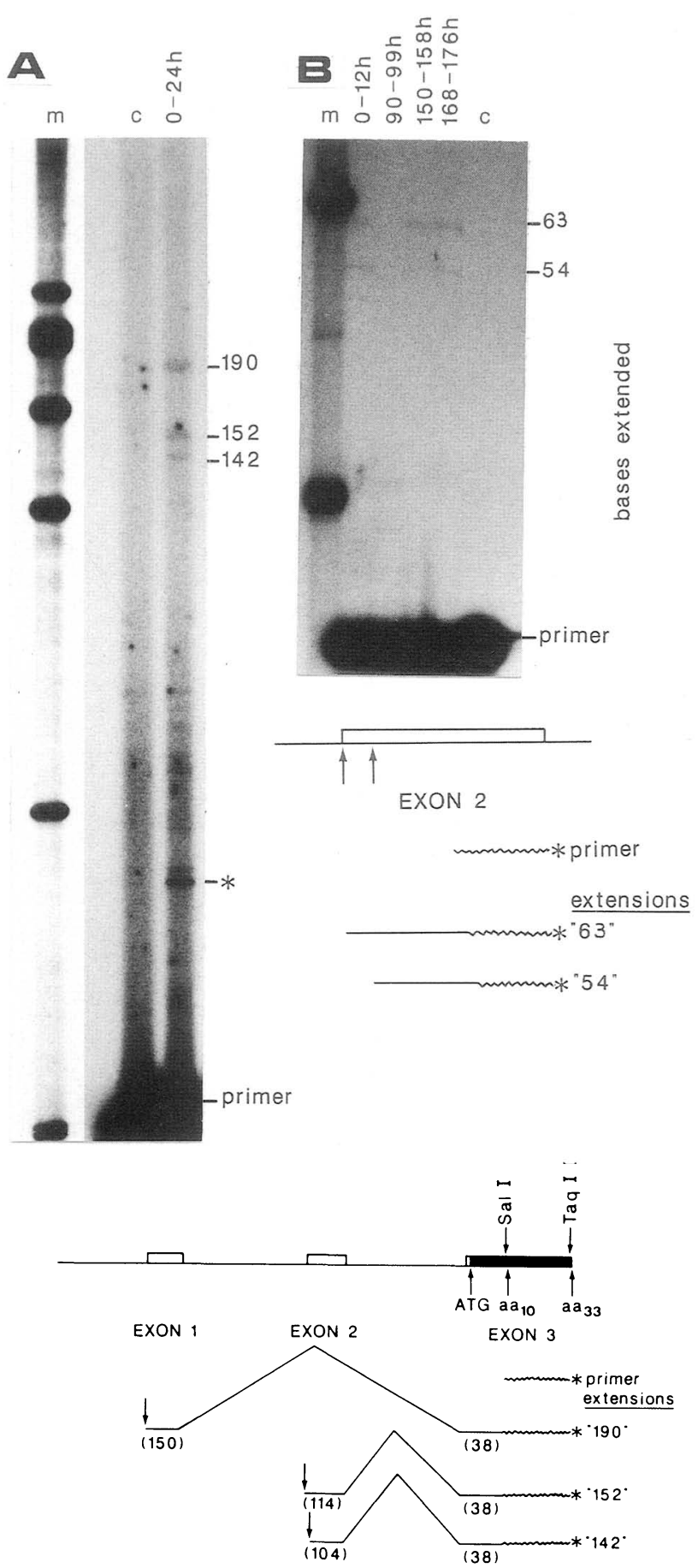

Figure 3. Mapping sites of transcription initiation by primer extension analysis. A 69-bp SalI-TaqI genomic fragment extending from +32 to +100 was $5^{\prime}$-end-labeled with polynucleotide kinase and used as primer for reverse transcription reactions with hybrid-selected, 5C actin poly(A) RNA. Yeast tRNA (c) was used as a control. (m) $\phi \mathrm{X}$ 174-HaeIII DNA fragments. Numbers on the right margin refer to number of nucleotides extended. The extension product marked with an asterisk $\left({ }^{*}\right)$ in $A$ probably results from degraded mRNA from the hybrid selection or premature termination, since it is not detected when total (unselected) poly(A) RNA is used as template. (B) Primer extension using a 53-bp HhaI-HindIII fragment from cDNA pD11. This fragment corresponds to nucleotides -655 to -603 of exon 2 .
Table 1. Quantitation of exon 1-versus exon 2-containing transcripts in embryo, larva, and pupa

\begin{tabular}{lccc}
\hline & $\begin{array}{c}\text { Embryo } \\
(0-12 \mathrm{hr})\end{array}$ & $\begin{array}{c}\text { Larva } \\
(90-99 \mathrm{hr})\end{array}$ & $\begin{array}{c}\text { Pupa } \\
(150-158 \mathrm{hr})\end{array}$ \\
\hline Exon 1 & $6.28 \pm 0.25$ & $7.70 \pm 0.29$ & $7.92 \pm 0.42$ \\
Exon 2A & $1.75 \pm 0.23$ & $1.57 \pm 0.29$ & $1.30 \pm 0.20$ \\
Exon 2B & $1.97 \pm 0.07$ & $0.73 \pm 0.19$ & $0.78 \pm 0.25$ \\
Exon 1/exon 2A & & & \\
$\quad+$ exon 2B & 1.69 & 3.35 & 3.81 \\
Exon 2A/exon 2B & 0.89 & 2.15 & 1.67 \\
\hline
\end{tabular}

Relative abundance of each exon was quantitated by densitometric scanning of autoradiograms of the ribonuclease protection assay. The area under each peak was determined with an electronic graphics calculator. The values shown (arbitrary units) represent the mean of three separate measurements for each of three different probes that overlap both exons. Hybridization was in probe excess (Zinn et al. 1983; Fischer and Maniatis 1986) as evidenced by a nonlinear correlation between input probe and intensity of the protected signal. To allow detection of low levels of exon 2-containing transcripts at 90-99 $\mathrm{hr}$, an overexposed autoradiogram (144 h; Fig. 2E) was used.

region of the gene which is spliced to one of two alternative $5^{\prime}$ noncoding exons. Exon 1 and exon 2 are separated from the coding exon by introns of approximately 1.66 $\mathrm{kb}$ and $0.59 \mathrm{~kb}$, respectively, and each exon accounts for all but 8 bp of the $5^{\prime}$ untranslated sequences present in $5 \mathrm{C}$ actin transcripts. The coding exon containing the entire open reading frame extends from position -8 /relative to the translation initiation codon) to one of three different polyadenylation regions, generating three distinct molecular weight classes of polyadenylated transcripts that differ in the length of their $3^{\prime}$ noncoding regions.

The transcription initiation sites were mapped by primer extension to define the $5^{\prime}$ boundaries of exon 1 and exon 2. A third initiation site has been mapped within exon 2, 10 nucleotides downstream from the second initiation site. Microheterogeneity of $5^{\prime}$ termini is a common feature of many genes (see, for example, Baker and Ziff 1981); however, this heterogeneity is usually within a shorter region (two to seven bases). Microheterogeneity could also be due to an artifact in the primer extension reaction resulting from an encounter of the reverse transcriptase with the $5^{\prime}$ cap structure (Chan et al. 1980). However, such doublets are never seen for the longest extension product (exon 1); thus, they are not due to cap structure alone. Second, a protected fragment corresponding to transcription initiation from this site is routinely observed in the RNase protection experiments. Exon mapping experiments in which RNase T2 (which is not sequence specific) was used instead of RNase A and RNase Tl also resulted in the 114/104-nucleotide protected fragment doublet (results not shown). The repeated appearance of this site in independent experiments leads us to propose that it represents a bona fide $5^{\prime}$ initiation site. Moreover, the stage-specific modulation of exon 2A- versus exon 2Bcontaining transcripts suggests that the sites are under separate genetic control. 


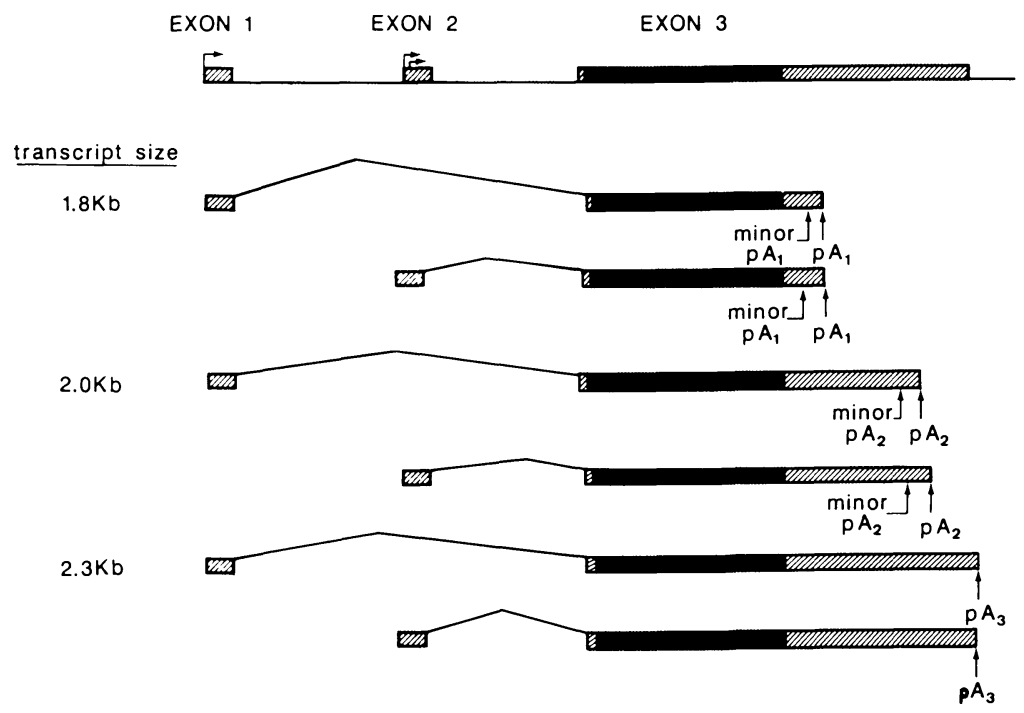

Figure 4. Schematic summary of the multiple 5C actin transcripts. Open reading frame is indicated by filled boxes and noncoding regions by striped boxes. Transcription initiation sites and cleavage/polyadenylation sites are also shown.

An analysis of the nucleotide sequence in the $5^{\prime}$ vicinity of exon 2 failed to reveal a consensus TATA box homology. This sequence has been shown to be involved in determining the proper site of transcription initiation (Benoist and Chambon 1981; Breathnach and Chambon 1981; Mathis and Chambon 1981). Several genes have been described that do not contain a typical TATA box and show multiple in vivo transcription initiation sites within a short region (Allen et al. 1983; Reynolds et al. 1984). Thus, the lack of a characteristic promoter region could be responsible for the two initiation sites associated with exon 2. Although we have not mapped the precise 5 ' end of exon 2 , our results allow us to conclude that this exon has two initiation sites that are approximately 10 nucleotides apart. Using the primer extension results, we have placed these two $5^{\prime}$ ends at positions -705 and -715 (Fig. 2). Bond and Davidson (1986) placed a single initiation site for exon 2 at position -711 . Unlike exon 2 , exon 1 is associated with a TATA box and only shows one transcription initiation site. Based on partial homology to a Drosophila cap consensus sequence (Hultmark et al. 1986), we assigned nucleotide -1820 as the transcription initiation site for exon 1. Bond and Davidson (1986) also designated this nucleotide as the start point, but Parker and Topol (1984) designated nucleotide -1822 as the start point.

The role of 5' leader sequences in bacterial transcription attenuation (Lee and Yanofsky 1977; Carter et al. 1986) and mRNA stability (Green and Inouye 1984; Belasco et al. 1986) is well documented. More recent studies have shown that untranslated leader regions of eukaryotic mRNA play a very important role in transcriptional and translational control (Darveau et al. 1985; McGarry and Lindquist 1985; Pelletier and Sonenberg 1985; Hultmark et al. 1986; Mueller and Hinnebusch 1986). In many cases, different length $5^{\prime}$ noncoding regions reflect transcription initiation from separate promoters, indicating that regulation lies at a transcriptional level (Benyajati et al. 1983; Schibler et al. 1983). In the case of the $5 \mathrm{C}$ actin gene, the two $5^{\prime}$ noncoding exons have very similar length ( $147 \mathrm{bp}$ vs. $114 \mathrm{bp}$ ) and sequence composition $(61 \%$ vs. $56.5 \% \mathrm{~A}+\mathrm{T})$, but they are utilized with different frequencies throughout development. The functional significance for these noncoding exons is not immediately evident, but there are several possibilities.

Each 5' exon could be under the control of a separate promoter that responds to different developmental, mitogenic, hormonal, or tissue-specific signals, thus conferring differential expression capabilities to this gene. The $5 \mathrm{C}$ gene encodes a cytoplasmic actin (Fyrberg et al. 1980) and it also has been shown to respond to hormonal stimulus (Couderc et al. 1983). Therefore, the existence of cis-regulatory elements that mediate $5 \mathrm{C}$ actin response to an array of transcription-controlling factors is not unlikely. The presence of multiple initiation sites could simply reflect the evolution of these transcriptional regulatory elements into separate entities. The divergence of the DNA sequence in the regions immediately preceding exon 1 and exon 2, together with the presence of a TATA box for exon 1 but not for exon 2, argues in favor of independent promoters for these two exons. Another possibility is that structural determinants exist within the two noncoding exons that are involved in separate aspects of post-transcriptional or translational control. These could include rapid changes in mRNA stability in response to a controlling signal such as a steroid hormone (Brock and Shapiro 1983), or differential ribosome binding efficiencies and therefore differential translational efficiencies (Pelletier and Sonenberg 1985). Finally, Lawrence and Singer (1986) have suggested that noncoding regions and, in particular, noncoding regions of actin transcripts could be involved in intracellular targeting (trafficking) of transcripts. Recent in situ hybridization experiments using probes representing either exon 1 or exon 2 sequences revealed 
completely different patterns of accumulation of exon 1versus exon 2-containing transcripts in embryonic tissue sections (J. Vigoreaux, T. Burn, and S. Tobin, unpubl.).

The steady-state level of each transcript size class varies through the developmental stages examined, suggesting that the mechanism(s) involved in polyadenylation site selection and/or $3^{\prime}$ end processing are under developmental control. Although $3^{\prime}$ untranslated sequences are a common feature of eukaryotic mRNAs, their function(s), if any, is unclear. Recent studies have revealed segments of homology that have been highly conserved among homologous genes from several species (Martin et al. 1981; Gunning et al. 1984; Yaffe et al. 1985), or among structurally unrelated genes that are functionally related (Caput et al. 1986). The existence of these conserved sequences suggests that $3^{\prime}$ noncoding regions, or at least subsegments of $3^{\prime}$ noncoding regions, may be involved in some aspect of gene regulation, possibly at either the transcriptional or post-transcriptional level. This is supported by recent studies identifying a conserved sequence in the $3^{\prime}$ noncoding region of certain mRNAs that appears to mediate the steady-state level of these molecules (Shaw and Kamen 1986). In addition, several studies have indicated that the translation efficiency of an mRNA could be determined by sequences in the 3' untranslated region (Liebhaber and Kan 1982; Miller et al. 1984; Treisman 1985). In particular, we noted that the transcripts with the longest 3 ' noncoding region (the $2.3 \mathrm{~kb}$ class) show the most modulation throughout development. Thus, it is possible that this region contains sequences that act as signals for a rapid mRNA turnover pathway that is active during particular developmental situations. Gene transformation experiments in which 3 ' noncoding regions are fused to easily identifiable reporter genes is one approach that could prove useful in addressing some of these issues.

The Drosophila 5C actin gene is the second actin gene that has been reported to produce multiple transcripts. Carroll et al. (1986) have reported that the chicken $\alpha$ smooth muscle (aortic) actin gene produces transcripts of four different sizes that are apparently the result of multiple polyadenylation site utilization. The developmental regulation of the use of these multiple polyadenylation sites was not investigated in this report. Primer extension experiments did not suggest the existence of $5^{\prime}$ heterogeneity in the transcripts from this actin gene (Carroll et al. 1986). Therefore, the study presented here is the first report of developmental specificity in the regulation of $5^{\prime}$ initiation/splicing patterns in the generation of actin transcripts in any organism.

\section{Materials and methods}

Isolation and subcloning of $5 \mathrm{C}$ actin genomic DNA

$5 C$ actin genomic DNA was isolated from the D. melanogaster phage $\lambda$ genomic bank of Maniatis et al. (1978) as described (Sanchez et al. 1983). The probe used was an actin plasmid (Kla) isolated from HindIII-cleaved D. melanogaster Schneider cell line 2 DNA (Tobin et al. 1980). An 8.4-kb EcoRI fragment containing the entire $5 \mathrm{C}$ actin gene was subcloned into the EcoRI site of pBR322. The cloned DNA was identified by in situ hybridization to polytene chromosomes (Gall and Pardue 1971) as described by Tobin et al. (1980). Isolation of DNA fragments through preparative agarose gels, subcloning into pBR322, transformation of E. coli RR1, and preparation of plasmid DNA were carried out as described (Tobin et al. 1980).

\section{Isolation, fractionation, and blotting of RNA}

RNA was isolated from developmentally staged whole organisms by a phenol extraction procedure (Lamb and Laird 1976) for embryo RNA or by the guanidinium isothiocyanate/ cesium chloride procedure of Chirgwin et al. (1979) as adapted by Tobin et al. (1980). Poly(A) RNA was selected by two successive fractionations through oligo(dT)-cellulose, electrophoresed on $1.5 \%$ formaldehyde agarose gels, and transferred with no further treatment to Biodyne nylon membranes (Pall Ultrafine Filtration Corp.) in $20 \times$ SSC for 18-24 hr (Maniatis et al. 1982). After transfer was completed, filters were air-dried for $1 \mathrm{hr}$ and baked for $2 \mathrm{hr}$ at $80^{\circ} \mathrm{C}$ in a vacuum oven.

Filters were prehybridized at $55^{\circ} \mathrm{C}$ for $4-8 \mathrm{hr}$ in $50 \%$ formamide, $50 \mathrm{~mm}$ sodium phosphate ( $\mathrm{pH} 6.5), 5 \times$ SSC, $0.1 \%$ SDS, $5 \times$ Denhardt's solution (Denhardt 1966), and $200 \mu \mathrm{g} / \mathrm{ml}$ denatured $E$. coli DNA. They were then hybridized to $3-5 \times 10^{5}$ $\mathrm{cpm} / \mathrm{ml}$ of probe in four parts prehybridization solution : 1 part $50 \%$ (wt/vol) dextran sulfate. Hybridizations were carried out at $55^{\circ} \mathrm{c}$ for $18-24 \mathrm{hr}$. Filters were washed once at room temperature for $30 \mathrm{~min}$ and $3-5 \times$ for $30 \mathrm{~min}$ each at $65^{\circ} \mathrm{C}$ in $0.1 \times$ SSC, $0.1 \%$ SDS. Filters were exposed to Kodak XAR- 5 or XAR-2 film using intensifying screens. Blots that were reused were washed at $90^{\circ} \mathrm{C}$ for $1-3 \mathrm{hr}$ in $50 \%$ formamide, $50 \mathrm{~mm}$ sodium phosphate $(\mathrm{pH} 6.5), 5 \times \mathrm{SSC}$, and $0.1 \%$ SDS.

\section{In vitro transcription with SP6 RNA polymerase and RNase mapping}

The plasmids used as templates for synthesizing singlestranded RNA probes were constructed by inserting the appropriate DNA fragment into compatible sites of the Riboprobe SP6 vectors pSP64 or pSP65 (Promega Biotec). Plasmids were propagated in E. coli RR1 and plasmid DNA prepared by centrifugation in cesium chloride gradients (Maniatis et al. 1982). Plasmids were linearized to completion with appropriate restriction enzymes that cut once within the cloned insert or the polylinker region, phenol-chloroform-extracted, and ethanolprecipated twice. These linear plasmid DNAs were used as templates for in vitro transcription with SP6 RNA polymerase as described by Melton et al. (1984) with the following modifications. Synthesis was carried out for $10 \mathrm{~min}$ at $40^{\circ} \mathrm{C}$ rather than for $\mathrm{l} \mathrm{hr}$ and the transcription mix was supplemented with $100 \mu \mathrm{M}$ unlabeled UTP when $\left[\alpha^{32}-\right.$ P $]$ UTP was used. These modifications resulted in almost $90-100 \%$ full-length probes as determined by electrophoresis on denaturing gels. After synthesis, the reaction was stopped with RQ1 DNase I (Promega Biotec) and extracted once with $1: 1$ phenol/chloroform; the RNA was purified from unincorporated ribonucleotides by Sephadex G-50 spin columns (Maniatis et al. 1982). The effluent was made $2 \mathrm{M}$ in ammonium acetate and ethanol-precipitated, and the pellet was resuspended in $\mathrm{H}_{2} \mathrm{O}$ and counted to quantitate incorporation.

RNase mapping was carried out by mixing $5 \mu \mathrm{g}$ of RNA with $8 \times 10^{5} \mathrm{cpm}$ of probe, heating for $10 \mathrm{~min}$ at $85^{\circ} \mathrm{C}$, and hybridizing overnight $(8-14 \mathrm{hr})$ at $45^{\circ} \mathrm{C}$ (Melton et al. 1984). Digestion with RNases was at $37^{\circ} \mathrm{C}$ for $30 \mathrm{~min}$. The resulting RNARNA hybrids were extracted once with $1: 1$ phenol/chloroform and precipitated with ethanol; the pellets were resuspended in $3 \mu \mathrm{l}$ of loading buffer and electrophoresed on $6 \%$ acrylamide -8 $M$ urea sequencing gels (Maxam and Gilbert 1980). ${ }^{32} \mathrm{P}$-Labeled 174- $\phi x$ HaeIII DNA fragments (New England Biolabs) were used as molecular weight standards. Autoradiograms were 
quantitated with the use of a soft laser scanning densitometer (Biomed Instruments) and the areas under the peaks were determined with an electronic graphics calculator (Numonics Corp, North Wales, Pennsylvania).

\section{Primer extension analysis}

A 69-bp SalI-TaqI fragment $(+32$ to +100$)$ was isolated and end-labeled by first removing 5 ' phosphates with alkaline phosphatase (Boehringer Mannheim), followed by replacement with $\left[\alpha^{-32}\right.$ P]ATP (Amersham) using T4 polynucleotide kinase. The labeled fragment $\left(0.1-1.0 \times 10^{6} \mathrm{cpm}\right)$ was mixed with hybridselected RNA in a solution containing $80 \%$ formamide, $0.4 \mathrm{M}$ $\mathrm{NaCl}, 10 \mathrm{~mm}$ PIPES ( $\mathrm{pH}$ 6.8), and $2 \mathrm{~mm}$ EDTA, heated for 10 min at $90^{\circ} \mathrm{C}$, and immediately transferred to $42^{\circ} \mathrm{C}$ overnight. After hybridization, the mixture was ethanol-precipitated and washed free of formamide with $70 \%$ ethanol. cDNA extension of RNA-DNA hybrids was carried out as described by Ingolia et al. (1980). The resulting extension products were extracted once with $1: 1$ phenol/chloroform and precipitated with ethanol, and the pellets were resuspended in loading buffer and electrophoresed on $6 \%$ acrylamide- $8 \mathrm{M}$ urea sequencing gels (Maxam and Gilbert 1980).

RNA homologous to the $5 \mathrm{C}$ actin $3^{\prime} 1.6-\mathrm{kb}$ HindIII-HindIII fragment was selected by the positive-hybridization technique of Ricciardi et al. (1979). DNA was digested with HindIII (for a total of $5 \mu \mathrm{g}$ of insert), and the fragments were separated on a $1 \%$ agarose gel and transferred to nitrocellulose (Southern 1975). The portion of the filter containing the 1.6-kb HindIIIHindIII insert was used to select homologous RNA from 30-50 $\mu \mathrm{g}$ of poly(A) RNA.

A 53-nucleotide primer from cDNA pD11 was isolated, endlabeled (see above), and digested with restriction enzyme HhaI to remove the GC tail; the products were separated on a $10 \%$ acrylamide preparative gel. The band corresponding to the 53nucleotide fragment was detected by autoradiography, excised from the gel, and the DNA electroeluted and processed as above. Primer extensions were done as described above except that hybridization was carried out at $45^{\circ} \mathrm{C}$.

\section{Isolation and characterization of cDNA clones}

cDNAs pD11 and pD12 were synthesized from poly(A) RNA isolated from third instar salivary gland induced in vitro with ecdysone (Wolfner 1980). Ten clones identified as actin cDNAs were kindly provided by G. Guild and $\mathrm{M}$. Wolfner. 5C actin cDNAs were identified by hybridization to the $5^{\prime}$ and 3 ' noncoding probes (see Fig. 1). Further characterization included restriction mapping. Southern blotting, and DNA sequence determination of selected regions.

A second cDNA library from imaginal disc RNA cloned into $\lambda$ gt 10 (kindly provided by J. Fristrom) was screened with a $5 \mathrm{C}$ actin coding region probe using standard screening techniques (Maniatis et al. 1982). An initial screen of $5 \times 10^{9}$ plaques produced 24 positives. Nine $5 \mathrm{C}$ actin clones were identified by hybridization to $5^{\prime}$ and $3^{\prime}$ noncoding probes. CDNA clones plD and $\mathrm{p} 3 \mathrm{~A}$ were isolated and subcloned into $\mathrm{pTZ}$ vectors (Pharmacia) and characterized as described above.

\section{DNA sequence analysis}

DNA sequencing was performed by the dideoxy chain-termination procedure of Sanger et al. (1977) using a commercial M13 cloning kit (Amersham). Restriction fragments were cloned directly into compatible sites of the vectors $\mathrm{M} 13 \mathrm{mpl} 8$ and M13mp19 following the procedures of Messing (1983). Overlapping sequence data were obtained by digesting the appropriate restriction fragment separately with Sau3A, TaqI, and Bal31.
Progressive shortening of target DNA by Bal31 was done by the procedure of Guo et al. (1983). pBR322 plasmids containing the 1.6-kb HindIII-HindIII genomic fragment and the 1.9-kb HindIII-HindIII genomic fragment were linearized with EcoRI. After treatment with Bal31, linear DNA molecules were bluntend-repaired with Klenow polymerase (Maniatis et al. 1982) and digested with HindIII and BamHI. Fragments were then cloned into HindIII-SmaI-cut M13mp19. For cDNA clones pD11 and pD12 (whose inserts are in the PstI site of pBR322), plasmid DNA was linearized with PvuI, followed by Bal31 treatment, Klenow repair, and digestion with PstI and BamHI. Fragments were cloned into PstI-SmaI-cut ml3mpl9. DNA sequences were analyzed using the computer programs GEL and SEQ developed by Intelligenetics (Palo Alto, California).

\section{Acknowledgments}

We would like to thank Greg Guild and Mariana Wolfner for the gift of actin cDNA clones and James Fristrom for providing the imaginal disc cDNA library. We appreciate the technical assistance of Patricia Cook in screening the cDNA library. We would also like to thank Olivia Hanson-Painton and Jay Hanas for reviewing this manuscript and Olivia Hanson-Painton for her help in the DNA sequence analysis. The assistance provided by Bruce Roe, Elaine Johnston, and Ricky Wong with the DNA sequence is also appreciated. We are grateful to Toni Johnson and Joyce Anderson for their patience in typing this manuscript. Sequence data were processed using the Bionet computer resource (Grant 1 U41 RR-01685-03). This work was supported by a grant from the National Institutes of Health (R01-GM32588) to S.T.

\section{Note}

Sequence data described in this paper have been submitted to the EMBL/GenBank Data Libraries under the accession number Y00212.

\section{References}

Allan, M., W.G. Lanyon, and J. Paul. 1983. Multiple origins of transcription in the $4.5-\mathrm{kb}$ upstream of the $\epsilon$-globin gene. Cell 35: 187- 197.

Baker, C.C. and E.B. Ziff. 1981. Promoters and heterogeneous 5' termini of the mRNAs of Ad 2. J. Mol. Biol. 149: 189-221.

Belasco, J.G., G. Nilsson, A. von Gabain, and S.N. Cohen. 1986. The stability of $E$. coli gene transcripts is dependent on determinants localized to specific mRNA segments. Cell 46: $245-251$.

Bennetzen, J.L. and B.D. Hall. 1982. The primary structure of the Saccharomyces cerevisiae gene for ADH1. I. Biol. Chem. 257: 3018-3025.

Benoist, C. and P. Chambon. 1981. In vivo sequence requirements of the SV40 early promoter region. Nature 290: 304310.

Benyajati, C., N. Spoerel, H. Haymerle, and M. Ashburner. 1983. The mRNA for alcohol dehydrogenase in Drosophila melanogaster differs in its $5^{\prime}$ end in different developmental stages. Cell 33: 125-133.

Bond, B.J. and N. Davidson. 1986. The Drosophila melanogaster actin 5C gene uses two transcription initiation sites and three polyadenylation sites to express multiple mRNA species. Mol. Cell. Biol. 6: 2080-2088.

Breathnach, R. and P. Chambon. 1981. Organization and expression of eukaryotic split genes coding for proteins. Annu. Rev. Biochem. 50: 349-383.

Breitbart, R.E., H.T. Nyguyen, R.M. Medford, A.T. Destree, V. Mahdavi, and B. Nadal-Ginard. 1985. Intricate combina- 
torial patterns of exon splicing generate multiple regulated troponin T isoforms from a single gene. Cell 41: 67-82.

Brock, M.L. and D.J. Shapiro. 1983. Estrogen stabilizes vitellogenin mRNA against cytoplasmic degradation. Cell 34: 207-214.

Buckingham, M.E. and A.J. Minty. 1983. Contractile protein genes. In N. McLean, S.P. Gregory, and R.A. Flavell, (ed.). Eukaryotic genes: Their structure, activity and regulation. pp. 365-395. Butterworths, London.

Capetanaki, Y.G., J. Ngai, C.N. Flytzanis, and E. Lazarides. 1983. Tissue-specific expression of two mRNA species transcribed from a single vimentin gene. Cell 35: 41 1-420.

Caplan, A.I., M.Y. Fiszman, and H.M. Eppenberger. 1983. Molecular and cell isoforms during development. Science 221: 921-927.

Caput, D., B. Beutler, K. Hartog, R. Thayer, S. Brown-Shimer, and A. Cerami. 1986. Identification of a common nucleotide sequence in the $3^{\prime}$ untranslated region of mRNA molecules specifying inflammatory mediators. Proc. Natl. Acad. Sci. 83: $1670-1674$.

Carlson, M. and D. Botstein. 1982. Two differentially regulated mRNAs with different 5 ' ends encode secreted and intracellular forms of yeast invertase. Cell 28: 145-154.

Carroll, S.L., D.J. Bergsma, and R.J. Schwartz. 1986. Structure and complete nucleotide sequence of the chicken $\alpha$-smooth muscle (aortic) actin gene. J. Biol. Chem. 261: 8965-8976.

Carter, P.W., J.M. Bartkus, and J.M. Calvo. 1986. Transcription attenuation in S. Typhimurium: The significance of rare leucine codons in the leu leader. Proc. Natl. Acad. Sci. 83: 8127-8131.

Chan, L., A. Dugaiczyk, and A.R. Means. 1980. Molecular cloning of the gene-sequences of a major apoprotein in avian VLDL. Biochemistry 19: 5631-5637.

Chirgwin, J.M., A.E. Przybyla, R.J. MacDonald, and W.J. Rutter. 1979. Isolation of biologically active ribonucleic acid from sources enriched in ribonuclease. Biochemistry 18: 52945299.

Cooper, T.A. and C.P. Ordahl. 1985. A single cardiac troponin T gene generates embryonic and adult isoforms via developmentally regulated alternative splicing. I. Biol. Chem. 260: $11140-11148$.

Couderc, J.L., M.L. Sobrier, G. Giraud, J.L. Becker, and B. Dastugue. 1983. Actin gene expression is modulated by ecdysterone in a Drosophila cell line. J. Mol. Biol. 164: 419-430.

Cox, K.H., L.M. Angerer, J.J. Lee, E.H. Davidson, and R.C. Angerer. 1986. Cell lineage-specific programs of expression of multiple actin genes during sea urchin embryogenesis. $J$. Mol. Biol. 188: 159-172.

Darveau, A., J. Pelletier, and N. Sonenberg. 1985. Differential efficiencies of in vitro translation of mouse c-myc transcripts differing in the $5^{\prime}$ untranslated region. Proc. Natl. Acad. Sci. 82: 2315-2319.

Davidson, E.H., T.L. Thomas, R.H. Scheller, and R.J. Britten. 1982. The sea urchin actin genes and a speculation on the evolutionary significance of small gene families. In (ed. G.A. Dover and R.A. Flavell), pp. 177-192. Genome evolution. Academic, New York.

Denhardt, D. 1966. A membrane-filter technique for the detection of complementary DNA. Biochem. Biophys. Res. Commun. 23: 640-646.

Early, P., J. Rogers, M. Davis, K. Calame, M. Bond, R. Wall, and L. Hood. 1980. Two mRNAs can be produced from a single immunoglobulin gene by alternative RNA processing pathways. Cell 20: 313-319.

Finnegan, D.J., G.M. Rubin, M.W. Young, and D.S. Hogness. 1977. Repeated gene families in Drosophila melanogaster. Cold Spring Harbor Symp. Quant. Biol. 42: 1053-1063.
Firtel, R.A. 1981. Multigene families encoding actin and tubulin. Cell 24: 6-7.

Fischer, J.A. and T. Maniatis. 1986. Regulatory elements involved in Drosophila Adh gene expression are conserved in divergent species and separate elements mediate expression in different tissues. EMBO I. 5: 1275-1289.

Freytag, S.O., A.L. Beaudet, H.G.O. Bock, and W.E. O'Brien. 1984. Molecular structure of the human argininosuccinate synthetase gene: Occurrence of alternative mRNA splicing. Mol. Cell. Biol. 4: 1978-1984.

Fyrberg, E.A., K.L. Kindle, N. Davidson, and A. Sodja. 1980. The actin genes of Drosphila: A dispersed multigene family. Cell 19: $365-378$.

Fyrberg, E.A., B.J. Bond, N.D. Hershey, K.S. Mixter, and N. Davidson. 1981. The actin genes of Drosophila. Protein coding regions are highly conserved but intron positions are not. Cell 24: 107-116.

Fyrberg, E.A., J.W. Mahaffey, B.J. Bond, and N. Davidson. 1983. Transcripts of the six Drosophila actin genes accumulate in a stage- and tissue-specific manner. Cell 33: 115-123.

Gall, J.G. and M.L. Pardue. 1971. Nucleic acid hybridization in cytological preparations. Methods Enzymol. 21: 470-480.

Garcia, R., B. Paz-Aliaga, S.G. Ernst, and W.R. Crain. 1984. Three sea urchin actin genes show different patterns of expression. Muscle specific, embryo specific, and constitutive. Mol. Cell. Biol. 4: 840-845.

Green, P.J. and M. Inouye. 1984. Roles of the 5 ' leader region of the ompA mRNA. I. Mol. Biol. 176: 431-442.

Gunning, P., T. Mohun, S. Ng, P. Ponte, and L. Kedes. 1984. Evolution of the human sarcomeric-actin genes: Evidence for units of selection within the $3^{\prime}$ untranslated regions of the mRNAs. J. Mol. Evol. 20: 202-214.

Guo, L., R.C.A. Yang, and R. Wu. 1983. An improved strategy for rapid direct sequencing of both strands of long DNA molecules cloned in a plasmid. Nucleic Acids Res. 11:55215540.

Hultmark, D., R. Klemenz, and W.J. Gehring. 1986. Translational and transcriptional control elements in the untranslated leader of the heat-shock gene hsp 22. Cell 44: 429438.

Ingolia, T.D., E.A. Craig, and B.J. McCarthy. 1980. Sequence of three copies of the gene for the major Drosophila heat shock induced proteins and their flanking regions. Cell 21: 669679.

Lamb, M.M. and C.D. Laird. 1976. The size of poly(A)-containing RNAs in Drosophila melanogaster embryos. Biochem. Genet. 14: 357-371.

Lawrence, J.B. and R.H. Singer. 1986. Intracellular localization of messenger RNAs for cytoskeletal proteins. Cell 45: 407415.

Lee, F. and C. Yanofsky. 1977. Transcription termination at the trp operon attenuators of $E$. coli and $S$. typhimurium: RNA secondary structure and the regulation of termination. Proc. Natl. Acad. Sci. 74: 4365-4369.

Leff, S.E., M.G. Rosenfeld, and R.M. Evans. 1986. Complex transcriptional units: diversity in gene expression by alternative RNA processing. Annu. Rev. Biochem. 55: 10911117.

Liebhaber, S.A. and Y. Kan. 1982. Different rates of mRNA translation balance the expression of the two human $\alpha$ globin loci. J. Biol. Chem. 257: 11852-11855.

Long, E.O. and I.B. Dawid. 1980. Repeated genes in euraryotes. Annu. Rev. Biochem. 49: 727-764.

Maniatis, T., R.C. Hardison, E. Lacy, J. Lauer, C. O'Connell, D. Quon, G.K. Sim, and A. Efstratiadis. 1978. The isolation of structural genes from libraries of eucaryotic DNA. Cell 15: $687-701$. 
Maniatis, T., E.F. Fritsch, and J. Sambrook. 1982. Molecular cloning: A laboratory manual. Cold Spring Harbor Laboratory, Cold Spring Harbor, New York.

Martin, S.L., E.A. Zimmer, W.S. Davidson, A.C. Wilson, and Y.W. Kan. 1981. The untranslated regions of $\beta$-globin mRNA evolve at a functional rate in higher primates. Cell 25: 737-741.

Mathis, D.J. and P. Chambon. 1981. The SV40 early region TATA box is required for accurate in vitro initiation of transcription. Nature 290: 310-315.

Maxam, A.M. and W. Gilbert. 1980. Sequencing end-labeled DNA with base- specific chemical cleavages. Methods Enzymol. 65: 499-560.

McGarry, T.J. and S. Lindquist. 1985. The preferential translation of Drosophila hsp70 mRNA requres sequences in the untranslated leader. Cell 42: 903-911.

McGrogan, M., C.C. Simonsen, D.T. Smouse, P.J. Farnham, and R.T. Schimke. 1985. Heterogeneity at the $5^{\prime}$ termini of mouse dihydrofolate reductase mRNAs: Evidence for multiple promoter regions. J. Biol. Chem. 260: 2307-2314.

McKeown, M. and R.A. Firtel. 1981. Differential expression and $5^{\prime}$ end mapping of actin genes in Dictyostelium. Cell 24: 799-807.

Melton, D.A., P.A. Krieg, M.R. Rebagliati, T. Maniatis, K. Zinn, and M.R. Green. 1984. Efficient in vitro synthesis of biologically active RNA and RNA hybridization probes from plasmds containing a bacteriophage SP6 promoter. Nucleic Acids. Res. 12: 7035-7056.

Messing, J. 1983. New M13 vectors for cloning. Methods Enzymol. 101: 20-78.

Miller, A.D., T. Curran, and I.M. Verma. 1984. c-fos protein can induce cellular transformation: A novel mechanism of activation of a cellular oncogene. Cell 36: 51-60.

Mohun, T.J., S. Brennan, N. Dathan, S. Fairman, and J.B. Gurdon. 1984. Cell type-specific activation of actin genes in the early amphibian embryo. Nature 311: 716-721.

Mueller, P.P. and A.G. Hinnebusch. 1986. Multiple upstream AUG codons mediate translational control of GCN 4. Cell 45: $201-207$.

Nabeshima, Y., Y. Fujii-Kuriyama, M. Maramatsu, and K. Ogata. 1984. Alternative transcription and two modes of splicing result in two myosin light chains from one gene. Nature 308: 333-338.

Parker, C.S. and J. Topol. 1984. A Drosophila RNA polymerase II transcription factor contains a promoter-region-specific DNA-binding activity. Cell 36: 357-369.

Pelletier, J. and N. Sonenberg. 1985. Insertion mutagenesis to increase secondary structure within the 5 ' noncoding region of a eucaryotic mRNA reduces translational efficiency. Cell 40: $515-526$.

Periasamy, M., E.E. Strehler, L.I. Garfinkel, R.M. Gubits, N. Ruiz-Opazo, and B. Nadal-Ginard. 1984. Fast skeletal muscle myosin light chains 1 and 3 are produced from a single gene by a combined process of differential RNA transcription and splicing. J. Biol. Chem. 259: 13595-13604.

Reynolds, G.A., S.K. Basu, T.F. Osborne, D.J. Chin, G. Gil, M.S. Brown, J.L. Goldstein, and K.L. Luskey. 1984. HMG CoA reductase: A negatively regulated gene with unusual promoter and 5' untranslated region. Cell 38: 275-285.

Ricciardi, R.P., J.S. Miller, and B.E. Roberts. 1979. Purification and mapping of specific mRNAs by hybridization selection and cell free translation. Proc. Natl. Acad. Sci. 76: 49274931.

Robert, B., P. Daubas, M.A. Akimenko, A. Cohen, I. Garner, J.L. Guenet, and M. Buckingham. 1984. A single locus in the mouse encodes both myosin light chains 1 and 3; a second locus corresponds to a related pseudogene. Cell 39: 129140.

Rosenfeld, M.G., J.J. Mermod, S.G. Amara, L.W. Swanson, P.E. Sawchenko, J. Rivier, W.W. Vale, and R.M. Evans. 1983. Production of a novel neuropeptide encoded by the calcitonin gene via tissue-specific RNA processing. Nature 304: 129133.

Sanchez, F., S.L. Tobin, U. Rdest, E. Zulauf, and B.J. McCarthy. 1983. Two Drosophila actin genes in detail: Gene structure, protein structure and transcription during development. $J$. Mol. Biol. 163: 533-551.

Sanger, F., S. Nicklen, and A.R. Coulson. 1977. DNA sequencing with chain- terminating inhibitors. Proc. Natl. Acad. Sci. 74: 5463-5467.

Schibler, U., O. Hagenbüchle, P.K. Wellauer, and A.C. Pittet. 1983. Two promoters of different strengths control the transcription of the mouse $\alpha$-amylase gene amy- $1^{a}$ in the parotid gland and the liver. Cell 33: 501-508.

Schneuwly, S., A. Kuroiwa, P. Baumgartner, and W.J. Gehring. 1986. Structural organization and sequence of the homeotic gene antennapedia of Drosophila melanogaster. EMBO I. 5: $733-739$.

Shaw, G. and R. Kamen. 1986. A conserved AU sequence from the 3' untranslated region of GM-CSF mRNA mediates selective mRNA degradation. Cell 46: 659-667.

Southern, E.M. 1975. Detection of specific sequences among DNA fragments separated by gel electrophoresis. $J$. Mol. Biol. 98: 503-517.

Tobin, S.L., E. Zulauf, F. Sanchez, E.A. Craig, and B.J. McCarthy. 1980. Multiple actin-related sequences in the Drosophila melanogaster genome. Cell 19: 121-131.

Treisman, R. 1985. Transient accumulation of c-fos RNA following serum stimulation requires a conserved 5 ' element and c-fos 3' sequences. Cell 42: 889-902.

Urano, Y., K. Watanabe, M. Sakai, and T. Tamaoki. 1986. The human albumin gene: Characterization of the $5^{\prime}$ and $3^{\prime}$ flanking regions and the polymorphic gene transcripts. $J$. Biol. Chem. 261: 3244-3251.

Vigoreaux, J.O. 1987. "Molecular structure and developmental expression of the 5C actin gene of Drosophila melanogaster: An actin gene with a complex transcriptional unit." Ph.D thesis, University of Oklahoma, Oklahoma City, Oklahoma.

Weydert, A., P. Daubas, M. Caravatti, A. Minty, G. Bugaisky, A. Cohen, B. Robert, and M. Buckingham. 1983. Sequential accumulation of mRNAs encoding different myosin heavy chain isoforms during skeletal muscle development in vivo detected with a recombinant plasmid identified as coding for an adult fast myosin heavy chain from mouse skeletal muscle. J. Biol. Chem. 258: 13867-13874.

Whalen, R.G., S.M. Sell, G.S. Butler-Browne, K. Schwartz, P. Bouveret, and I. Pinset. 1981. Three myosin heavy chain isozymes appear sequentially in developing rat muscle. $\mathrm{Na}$ ture 292: 805-809.

Wolfner, M. 1980. Dissertation, Stanford University, Palo Alto, California.

Yaffe, D., U. Nudel, Y. Mayer, and S. Neuman. 1985. Highly conserved sequences in the $3^{\prime}$ untranslated region of mRNAs coding for homologous proteins in distantly related species. Nucleic Acids Res. 13: 3723-3737.

Zinn, K., D. DiMaio, and T. Maniatis, 1983. Identification of two distinct regulatory regions adjacent to the human $\beta$-interferon gene. Cell 34: 865-879. 


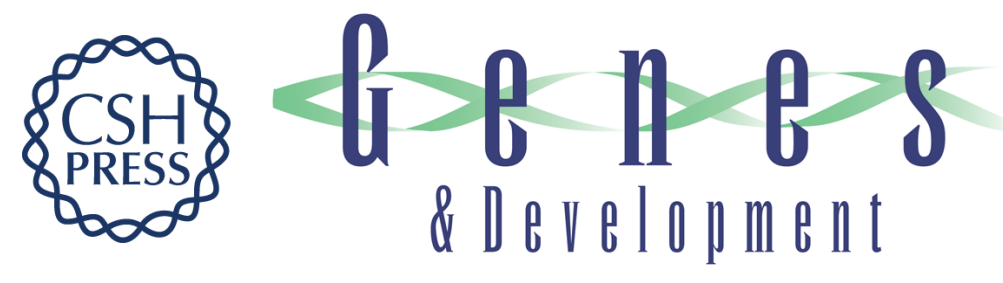

\section{Stage-specific selection of alternative transcriptional initiation sites from the $5 \mathrm{C}$ actin gene of Drosophila melanogaster.}

J O Vigoreaux and S L Tobin

Genes Dev. 1987, 1:

Access the most recent version at doi:10.1101/gad.1.10.1161

References This article cites 77 articles, 18 of which can be accessed free at: http://genesdev.cshlp.org/content/1/10/1161.full.html\#ref-list-1

License

Email Alerting

Receive free email alerts when new articles cite this article - sign up in the box at the top Service right corner of the article or click here.

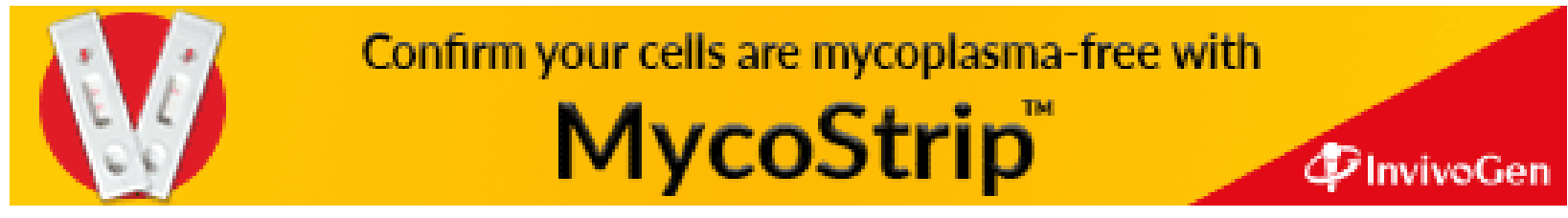

